Please note this the authors' pre-publication draft copy of the article published in the Journal of Service Management (2013). The original publication is available at DOI: $10.1108 /$ JSOM-

04-2013-0092

Conceptual paper

\title{
Social layers of customer-to-customer value co-creation
}

Ivana Rihova²*, Dimitrios Buhalis ${ }^{2}$, Miguel Moital² and Mary-Beth Gouthro²

${ }^{1}$ International Centre for Tourism and Hospitality Research, Bournemouth University, Poole, UK

${ }^{2}$ School of Tourism, Bournemouth University, Poole, UK

*Correspondence to:

Dr Ivana Rihova, School of Marketing, Tourism and Languages, The Business School, Edinburgh Napier University, Craiglockhart Campus, Edinburgh, EH14 1DJ, UK. Email: i.rihova@ napier.ac.uk

\begin{abstract}
Purpose - Approached from the customer-dominant (C-D) logic perspective, this paper aims to extend current value co-creation discussions by providing conceptual insights into cocreation within customers' social sphere. Focusing on socially dense contexts in which customers consume together in dyads or collectives, the paper seeks to provide recommendations of how service managers can facilitate customer-to-customer (C2C) cocreation. Design/methodology/approach - The paper bridges current thinking on value within the C-D logic with service management perspectives on $\mathrm{C} 2 \mathrm{C}$ interactions and social science concepts on consumer communities. Examples from literature and practice are drawn on in the discussion. Findings - The proposed framework reveals $\mathrm{C} 2 \mathrm{C}$ co-creation as a dynamic, multi-layered process that is embedded in customers' social contexts. Value emerges in four distinctive social layers: "detached customers", "social bubble", "temporary communitas" and "ongoing neo-tribes". Research limitations/implications - This paper is conceptual. Further validation of the framework in a variety of socially dense consumption settings is needed, using field-based qualitative methods such as participant observation and interviews. Practical implications - Awareness of the multi-layered nature of $\mathrm{C} 2 \mathrm{C}$ cocreation and specific practices in which value is formed provides service managers with opportunities to create value propositions that help facilitate such co-creation. Service managers across various sectors benefit from understanding how customers can be "nudged" into more socially immersive co-creation layers. Originality/value - The paper contributes by introducing a $\mathrm{C} 2 \mathrm{C}$ co-creation perspective, conceptualizing the social layers within which value is formed, and providing specific propositions to service managers with regard to servicescape structuring and other strategies that facilitate $\mathrm{C} 2 \mathrm{C}$ co-creation.
\end{abstract}

Keywords: Customer-dominant logic, Customer-to-customer, Shared consumption, Value co-creation

\section{When citing this publication, please use the following reference:}

Rihova, I., Buhalis, D., Moital, M., Gouthro, M-B. (2013) Social layers of customer-tocustomer value co-creation. Journal of Service Management, 24 (5), 553 - 566. 


\section{Social layers of customer-to-customer value co-creation}

\section{Introduction}

The service-dominant [S-D] logic of marketing (Vargo and Lusch, 2004; 2008) conceptualizes value co-creation in terms of interactive processes between the customer and the service provider. However, not enough attention is given to co-creation that take place as customers interact with each other. In certain socially dense consumption contexts such customer-to-customer [C2C] co-creation processes can have very important implications. During visits to shopping malls, organized leisure or adventure tours, golf tournaments, cruises, or special events and festivals, services are consumed simultaneously by a number of customers who socialize, interact and share their consumption experiences with each other. With a small number of exceptions (e.g., Baron and Harris, 2008; Finsterwalder and Kuppelwieser, 2011; McColl-Kennedy et al., 2012), service research does not commonly consider these $\mathrm{C} 2 \mathrm{C}$ processes as a potential source of value co-creation - a gap this paper attempts to address conceptually.

The recently emerged customer-dominant [C-D] logic (Heinonen et al., 2013; 2010; Voima et al., 2010) offers a useful basis for understanding C2C co-creation as it places customers' value creation in centre of enquiry. C-D logic does not, however, explain where precisely within the customers' social sphere value is actually created, or formed, and whether/ how such $\mathrm{C} 2 \mathrm{C}$ co-creation could be managerially facilitated. This paper bridges current customerdominant logic in service research on value co-creation and formation with managementoriented perspectives from services marketing but also with social science concepts outside the management discourse, in order to suggest new insights into how 'social layers of $\mathrm{C} 2 \mathrm{C}$ value co-creation' can be conceptualized. A framework is proposed that positions customers' $\mathrm{C} 2 \mathrm{C}$ co-creation in a number of social layers, and provides propositions and recommendations for service managers who wish to facilitate $\mathrm{C} 2 \mathrm{C}$ co-creation of value in socially dense consumption contexts more effectively.

\section{Co-creation of value in services research}

Service-dominant logic and service-related value co-creation 
S-D logic in marketing conceptualizes value and re-defines the relationship between the service organization and customers. Introduced by Vargo and Lusch in 2004 as a new paradigm in marketing, S-D logic focuses on customers' role in co-creating value and valuable experiences with the service organization. Vargo and Lusch (2004) argue that, in the increasingly dynamic, process-oriented context of customer experiences, the role of the service provider is limited to offering 'value propositions' to customers. Value is co-created as both the service organization and its customers employ and integrate various 'operand' (tangible resources that can be allocated or 'acted upon', such as natural resources) and 'operant' resources (often infinite and intangible skills or competencies over which the actors have 'authoritative' capability and that 'act on' other resources to produce effects) (ibid). Conceptualization of value realized through co-creation in S-D logic builds on Holbrook's notion of value as something that "resides not in the product purchased, not in the brand chosen, not in the object possessed, but rather in the consumption experience( $s$ ) derived therefrom" (1999, p. 9 emphasis in original). The highly subjective and phenomenological value-in-use (Vargo and Lusch, 2004) is co-created with and ultimately determined by the customer as a result of their service experience. In their later re-conceptualizations of value Vargo and Lusch (2008) emphasize the importance of networked nature of value beneficiaries and contextual features of consumption. Value-in-use is supplemented with a broader 'value-in-context' that can go well beyond the value proposition intended by the marketer. In co-creating value-in-context, customers draw on a number of social resources which include family relationships, communities, and commercial relationships (Arnould et $a l ., 2006)$, thus 'determining and enhancing' their experiential value outcomes in a contextualized manner (Baron and Harris, 2008).

Because of the emphasis of co-creation research on the subjective, phenomenological nature of value determinations of networked customers, researchers typically aim to establish or quantify specific types of realized value outcomes perceived by customers or customer communities. For instance, typologies of social, epistemic and conditional consumption value (Sheth et al., 1991) or other-oriented 'status' and 'esteem' consumer value (Holbrook, 1999) are utilized to determine perceived utility of consumption choices on the purchase decision-making level (Sweeney and Soutar, 2001). Similarly, social aspects in consumption situations are taken into consideration when determining potential customer value outcomes (Bearden and Etzel, 1982; Belk, 1975). However, while such research aims to reflect a customer-oriented perspective and the social influences on value co-creation, it tends to focus 
predominantly on the emergence of provider- or service-related value, i.e. value that necessarily pertains to contextualized experiences of using service providers' value offering (Payne et al., 2008; Vargo and Lusch, 2006).

In order to fully acknowledge customers' perspective on value, marketing needs to adopt a mindset in which the customer is the sole creator of value, while the firm joins in as a supporter/ facilitator of customers' value creation (Grönroos, 2008). In addition, understanding how customers define or experience value as outcomes remains an important subject in marketing. Nonetheless, the processes through which value is actually created are equally as important as a research subject (Gummerus, 2013). The notion of value being created throughout customers' social experiences and practices as seen in the emerging customer-dominant perspective is in line with this mindset. It gives primacy to value creating processes that may be embedded in customers' wider social context, outside the service providers' influence.

\section{Customer-dominant logic and value formation}

Helkkula et al. (2012) point out that customers' value experiences do not always correspond with service providers' proposed value offerings, as these may not be integrated into the customers' complex social contexts. Experiences staged by festival organizers, for instance, do not necessarily correspond fully with the deep social meanings that committed customers attach to their membership in on-going social networks (Begg, 2011; Kim and Jamal, 2007). Retail customers in online environments construct and manifest their own social experiences both on-line and off-line (Rosenbaum, 2008; Rowley et al., 2007), while service contexts and value propositions serve merely as the focus of such experiences. Value creation in these circumstances could then be described as taking place primarily in the customers' sphere (Grönroos, 2008), with marketer-provided value propositions serving merely as a 'platform' for customers' C2C value creation (Gummerus, 2013).

Such customer-centric orientation is evident in the very recently emerged customer-dominant (C-D) logic (Heinonen et al., 2010; 2013; Voima et al., 2010), which helps us to refocus attention away from value creation as something that is always service-related toward something that stems from the social experiences and practices among customers. The C-D perspective posits that rather than treating their customers as partners in co-creation, service organizations should strive to find out what customers actually do with the service in the 
context of their lives and to accomplish their own goals. As Heinonen et al. (2010, p. 533) point out, service providers would benefit from "a holistic understanding of the customers' lives, practices and experiences, in which service is naturally and inevitably embedded". Such contextual and interpretative enquiry into the dynamic interplay between customers' social activities, practices and experiences could be converted into concrete ways for service providers to support and facilitate customers' value creation (Grönroos and Voima, 2013).

C-D logic develops further S-D logic's view of value as a phenomenological construct. The notion of 'value-in-the-experience' (Helkkula et al., 2012) is introduced. Building on Husserl's ([1936] 1970) phenomenology and the concept of lived experiences, this perspective emphasizes not only the intra-subjective interpretations of value within lived experiences, but also inter-subjective value that emerges from individually determined social contexts (Helkkula et al., 2012). In this way, value-in-the-experience differs from previous experiential value notions in that it does not limit itself to subjectively perceived value outcomes that are merely influenced by some social contextual factors, as suggested by traditional value perspectives. Rather, these social factors are already inherent in customers' value creation processes. As consumption in these settings takes place in the company of other customers, experiences are often shared, rather than purely personal and subjective. Thus, the inter-subjective (i.e., mutual or dyadic co-creation between two and more customers) and collective (i.e., co-creation experiences shared among a group of community of customers) value dimensions also need to be explored (Edvardsson et al., 2011; Pareigis et al., 2012; Voima et al., 2010).

Furthermore, as value emerges mostly in the customers' sphere, beyond the visibility of the service provider (Heinonen et al., 2010), focusing on customers' social experiences within specific service contexts becomes problematic. The C-D perspective therefore emphasizes customers' ongoing social practices and experiences in the context of their lives. This 'emerging' nature of value in customers' experiences and practices is reflected in C-D logic abandoning the term value co-creation in favor of value creation or formation. While this paper still utilizes the term ' $\mathrm{C} 2 \mathrm{C}$ co-creation', we view it in line with $\mathrm{C}$-D logic's value processes conceptualization; that is, as an umbrella term for both inter-subjective (customerto-customer) and collective processes in which value-in-the-experience is formed. This perspective focuses on the 'where' and 'how' of $\mathrm{C} 2 \mathrm{C}$ co-creation rather than on its outcomes.

\section{Conceptualizing social layers of $\mathrm{C} 2 \mathrm{C}$ value co-creation}


Conceptually, C-D logic is useful in helping to understand C2C co-creation. Nevertheless, little is known about where in the customers' social sphere value-in-the-experience is formed in socially dense consumption contexts. Researchers who explore $\mathrm{C} 2 \mathrm{C}$ interactions in such contexts mostly adopt a subjectivist, experiential perspective in that they focus predominantly on the perceived positive, negative or neutral value outcomes of social atmospherics (e.g., Uhrich and Benkenstein, 2011), or the influence of other customers on service experiences (Huang and Hsu, 2010). While these studies highlight the fact that customers co-create value with each other, other customers are viewed merely to comprise a social element of the servicescape that may impinge on individuals' service experiences.

A small number of studies have explicitly explored $\mathrm{C} 2 \mathrm{C}$ co-creation processes within the realms of collective consumption. For instance, Baron and Harris (2008) looked at how a customer group integrated their operant resources to co-create a collective kind of value in their bid to save a local cinema. Finterwalder and Kuppelweiser (2011) conceptualized cocreation in group-forming processes within co-consumer groups and McColl-Kennedy et al. (2012) explored value-creating practices of patient networks in healthcare settings. While these studies advance to some extent our understanding of $\mathrm{C} 2 \mathrm{C}$ co-creation, there is still a gap in knowledge with respect to a move toward a holistic conceptualization of customers' social sphere in which value is formed.

Table 1 summarizes the 'where' of $\mathrm{C} 2 \mathrm{C}$ co-creation in socially dense consumption contexts in four layers: 'Detached Customers', 'Social Bubble', 'Temporary Communitas' and 'Ongoing Neo-tribes'. The characteristics of each layer (the 'who' and 'what') are discussed in detail in what follows, together with opportunities and recommendations for service managers to facilitate value formation, and also to potentially 'nudge' customers into 'higherorder' layers. Examples from tourism and festivals in particular are drawn on in the discussion as they represent a useful context for theoretically exploring $\mathrm{C} 2 \mathrm{C}$ co-creation. Festivals not only offer an opportunity for a variety of customer social units to come together to bond, socialize and commune in one place (Gibson and Connell, 2012), but also to form long-lasting, neo-tribal communities of interest (Begg, 2011). As such they can offer interesting insights for service managers dealing in a variety of other socially dense consumption contexts.

* Table 1 about here 


\section{'Detached Customers' layer}

In many socially dense contexts there is typically a small number of customers who visit on their own or with a single partner, co-creating within a 'Detached Customers' layer. Individualism and need for privacy can be relatively high with few opportunities for active interactions with strangers sought, giving way to insular and territorial behaviours. Wilks (2012) writes about the tendency of couples visiting opera festivals to 'close themselves off' in festival environments and not interact with anyone else at the festival. Couples at campsites often seek distance from others by camping away from the crowd, or by seeking out quieter corners in the service landscape, in order to relax and contemplate together. Tourists on beaches may erect windbreakers around themselves in order to protect their privacy.

A generally friendly social atmosphere can nevertheless still be present even if the Detached Customers co-creation layer prevails. Couples in tourism and leisure settings often assist strangers; for instance, campers who may not normally seek out interactions with strangers will still lend their mallet to 'tent neighbours' or offer lifts to a stranger (Filimonau et al., 2013). Similarly, individuals in retail, hospitality and leisure environments may want to occasionally provide advice to other customers (McGrath and Otnes, 1995; Rosenbaum, 2008).

\section{Service management implications:}

Tourism and leisure experiences in particular often represent an opportunity to escape from the usual social environment (Kim and Jamal, 2007; Kozinets, 2002). For some customers the socially dense context represents an opportunity to experience a different kind of holiday with their partner, with other customers in the settings as mere background to their interpersonal co-creation. While insular practices may seem detrimental to the emerging social value-in-the-experience, self-contained tent areas that spring up at festival campsites can help to facilitate a sense of separation (Begg, 2011). In such cases the physical setting can be designed to allow for private contemplation. For instance, relaxation areas with smaller sectioned-off, cosy spaces with books and magazines, or areas where individuals and couples can play parlour games, help facilitate practices and experiences within this layer.

To help 'nudge' customers into more socially intensive co-creation layers service managers should support positive critical incidents among customers-strangers both within the service contexts and outside it. Collaborative and helping practices should be nurtured through an 
appropriate 'code of conduct'; for instance on their website festivals encourage customers to arrange shared transport. Amiable encounters and conversations with strangers can be facilitated by introducing dining areas with smaller tables. 'Customer compatibility' (Martin and Pranter, 1989) can be managed by targeting and bringing together individuals and couples with similar features in specific situations, such as special-interest workshops.

\section{'Social Bubble’ layer}

Consumption experiences are often shared in larger groups of known acquaintances, friends and family members. Time spent together and the sharing and remembering of specific experiences is one of the main sources of value in the Social Bubble layer. Groups of women go shopping together to catch up over lunch as well as affirm their fashion choices.

Smuggling alcohol into festival venues can be seen by groups of friends as 'an adventure' that re-enforces the bonds among them, while shared memories last long after (Lehto et al., 2009). Families may use shared consumption as an opportunity to reinforce particular family traditions and identities; Kyle and Chick (2002) discuss how family gatherings at an annual agricultural strengthen family rituals and traditional gender roles.

Customers co-creating within the Social Bubble layer tend to be less insular; for example, groups may invite strangers to join into their activities, playing Frisbee, football or tennis are popular group activities in leisure settings that may involve strangers. The goal-oriented nature of together overcoming some challenge may give rise to a sense of social flow among those participating (Arnould and Price, 1993; McGinnis et al., 2012; Walker, 2010), thereby veering into the more collective temporary community-like co-creation layer.

\section{Service management implications:}

By targeting family and friend group customer segments service managers can support the formation of strong bonding value-in-the-experience. The importance of introducing family members and friends to new experiences is of significance, as traditions that revolve around shared consumption in specific contexts could lead to future loyalty behaviors (Kyle and Chick, 2002). Physical space can be arranged so that groups can be near each other; campsite operators can for example section off family-specific pitches and encourage visitors to come together, so that such social units do not need to break up. Online intra-group co-creation can also be leveraged, for example by tapping into family and friend groups sharing their consumption experiences on social media platforms. In the spirit of the new 'kinship 
economy' recently coined in marketing practice (Smith, 2012), service organizations can aim to integrate themselves with customers' communication practices with their social peers. Organizations in retail and tourism sectors for instance already encourage sharing of branded content through social media such as Twitter or Facebook prior- or post- consumption (Binkhorst and Den Dekker, 2009; Neuhofer et al., 2012).

Furthermore, supporting inter-group bonding through flow-inducing activities and program features aimed at families and larger groups could help to nudge numerous 'Social Bubbles' toward the Temporary Communitas layer. Festivals for instance can organize child-friendly crafts workshops, and hotels and campsites can provide team-games facilities, helping to involve strangers in co-creation practices of known-groups.

\section{'Temporary Communitas' layer}

C2C co-creation within a 'Temporary Communitas' reflects the 'liminoid' (Turner, 1995) nature of many socially dense contexts. According to Turner (1995) customers in liminoid environments find themselves removed from their ordinary place and time, in a 'place out of place' where 'rites of integration' help to reverse everyday, conventional norm and rule structures. Such rituals lead to the production of a sense of closeness and camaraderie among participants, which Turner (1995) describes as communitas.

Temporary communitas typically form during leisure and tourism experiences, but can also emerge in a variety of 'third places', such as cafes and diners, bars, cinemas and health establishments. Festival attendees, for instance, experience shared feelings of goodwill and a sense of being part of something bigger. The unity and leveling of social barriers in liminoid environments is intensified in conditions where customers find themselves in a similar 'backto-basics' states, forced to leave most possessions behind (Arnould and Price, 1993). Consequently, they identify themselves with strangers, typically introducing themselves by first names only and then developing very strong friendships and connections which may transcend the immediate social situation.

\section{Service management implications:}

Service managers benefit from creating environments that facilitate the leveling of social barriers and enhancing communing practice among customers. Attracting customers with a common interest and for a common purpose can help facilitate a sense of unity. More importantly, however, leveling of social barriers can be leveraged by emphasizing the 
liminoid features of the consumption setting. For example, festivals and shopping malls mark out the ritualistic transformation from the usual to the 'other-worldly' consumption space through colorful gateways, flags, lighting and festivity symbols such as circus-like structures and art-based performances. Dressing customers in costumes or uniforms also helps to facilitate a sense of shared identity and equality (Arnould and Price, 1993), and can also provide an entertainment element.

Customers are encouraged to form a shared sense of excitement by well-trained staff and through effective programming. Initiatives such as 'flash mobs' can enliven retail and public spaces and temporarily create a sense of togetherness among those present. For instance, Roskilde music festival organizers bring large numbers of people who do not know each other together in the setting and, using pre-recorded media messages played on participants' media devices, orchestrate on-site customer activities such as 'silent disco' or 'mass hugging'. Managers then benefit from facilitating formation of more permanent bonds and socialization outside the service context, and supporting emergence of on-going customer neo-tribes.

\section{'Ongoing Neo-tribes' layer}

'Ongoing Neo-tribes' as the fourth $\mathrm{C} 2 \mathrm{C}$ co-creation layer reflects social practices performed among members of consumer subcultures and neo-tribes (Maffesoli, 1996 [1988]). Customers often express their belonging to a specific neo-tribe by wearing particular clothes, consuming particular food and drinks or using particular discourse (Maffesoli, 1996 [1988]). Specialist knowledge, skills and experience are often shared and exchanged when neo-tribe community members come together both in physical and online contexts (Schau et al., 2009). For instance, VolksWagen campervan owners interact on www.vwforum.com; and, backpackers visit the www.couchsurfing.org forum in order to look for accommodation, meet new likeminded people and exchange advice and specialist knowledge. Community membership that goes beyond the physical service experience can form basis for formation of social capital, such as reciprocity, social trust and well-being, through what Cova (1997) terms 'linking value'.

Service management implications:

This layer can prove the most hard to reach for service providers, as the members of neotribes often take their co-creation practices away from specific service contexts. Nonetheless, 
a number of researchers argue that service managers can access this layer in order to source from their customers potential input for product and service improvement and innovation (Pongsakornrungsilp and Schroeder, 2011; Russo-Spena and Mele, 2012; Rowley et al., 2007). In this vein, service managers might attempt to host Internet forums and social media sites in which customer communicate with each other about their interests and experiences. On site, managers can then foster the exchange and sharing of interest-specific know-how and resources through programming and special design, such as 'open-mike' and 'round-thefire' jamming sessions at music festivals, or 'speed-dating' style resource trading events at campsites or in retail settings, where experienced individuals can help and share their knowhow with less experienced customers.

A sense of belonging and emotional connection can be fostered by tapping into, and mimicking to some extent, tribal practices and symbolism (Rosenbaum and Massiah, 2011); for instance, festival organisers catering to folk music enthusiasts serve ale in pewter tankards and incorporate retail units on site that sell alternative clothing and musical instruments. Tshirts and various accessories could be sold that combine in their design a specific brand with symbolism familiar to the community of interest.

\section{Conceptual framework}

Framework presented in Figure 1 summarizes the discussion so far. The four $\mathrm{C} 2 \mathrm{C}$ co-creation layers are illustrated in the lower half of the framework as a progression of customers' practices within 'Customers' social sphere'. Customers may or may not progress from the less socially immersive 'Detached Customers' layer, through group-centric 'Social Bubble' layer, toward more spontaneous socializing and connecting with other unknown customers in the 'Temporary Communitas' layer, and finally forming long-lasting bonds within the 'Ongoing Neo-Tribes' layer. Value-in-the-experience that is formed in practices within each layer is also highlighted.

* Figure 1 about here

Recommendations for service managers provided with respect to how $\mathrm{C} 2 \mathrm{C}$ co-creation within each layer could be supported through configuration of hard and soft service aspects of the servicescape (Bitner, 1992; Rosenbaum and Massiah, 2011) are illustrated in the 'Service manager sphere' in the top half of the framework. The large down-pointing arrow indicates the role of service managers in embedding their onstage and online activities in customers' on-going practices and experiences (Heinonen et al., 2013). Boundaries between each C2C 
co-creation layer offer opportunities for managers to potentially 'nudge' customers into more socially immersive $\mathrm{C} 2 \mathrm{C}$ co-creation layers. Strategies include facilitating stranger encounters and positive critical incidents; leveling social barriers and highlighting the liminoid features of the service experience; and, supporting on-going memberships in customer communities and neo-tribes.

\section{Conclusion}

This paper highlighted under-researched, yet very important issues in co-creation research. We have argued that as experiences in socially dense consumption contexts are often shared with friends, family and unfamiliar strangers, $\mathrm{C} 2 \mathrm{C}$ co-creation needs to be considered as a dynamic and holistic phenomenon that is embedded in customers' social sphere and at the same time can progress through multiple social layers. Through conceptualizing these layers we hope to have been able to provide useful insights for those who wish to facilitate and support customers' $\mathrm{C} 2 \mathrm{C}$ co-creation processes and the value formed in these.

The discussion in the paper revolves largely around examples from tourism and festival contexts. The framework provided is nevertheless of interest to managers in various other service contexts where consumption is shared and collective, such as shopping mall visits, sports events, visiting night clubs, dining in restaurants, attending business networking events, political gatherings, arts performances, support groups within public health initiatives, or speed-dating events. Furthermore, insights presented here indicate how value formed in insulating, bonding, communing and belonging practices could help illuminate the appeal of shared consumption experiences in physical contexts in particular. While customers increasingly interact with each other on Web 2 and social media platforms (Neuhofer et al., 2012), service organizations such as shopping malls can benefit from recognizing the importance of actually bringing customers together in physical contexts (Storper and Venables, 2004), as festivals and gatherings do.

Future research should apply and test the framework empirically in a number of socially dense consumption contexts. Such enquiry would benefit from adopting qualitative methodological approaches grounded in an interpretivist, as opposed to a positivist, outcomeoriented paradigm. In-depth ethnographic approach, for instance, would take the unique and often complex social elements of the consumption context into account (Goulding and 
Shankar, 2011; Kozinets, 2002), and at the same time would offer a more exhaustive overview of specific practices within the different $\mathrm{C} 2 \mathrm{C}$ co-creation layers.

Furthermore, value-in-the-experience exemplified in the $\mathrm{C} 2 \mathrm{C}$ co-creation layers will likely emerge differently for different customers and customer groups, depending on a number of factors. For instance, customers' goals and motivations (McColl-Kennedy et al., 2012) and operant resources (Arnould et al., 2006), as well as a number of context- and situationspecific factors, such as those identified in the framework, will potentially influence which layer value is formed in. While a closer inspection of these factors is outside the scope of this paper, future research should aim to identify and explore in depth the personal and contextual elements that influence $\mathrm{C} 2 \mathrm{C}$ co-creation. 


\section{References}

Arnould, E. J. and Price, L. L. (1993), "River magic: extraordinary experience and the extended service encounter", The Journal of Consumer Research, Vol. 20 No. 1, pp. 24-45.

Arnould, E. J., Price, L. L. and Malshe, A. (2006), "Toward a cultural resource-based theory of the customer", in Lusch, R. F. and Vargo, S. L. (eds.), The service-dominant logic of marketing: dialog, debate and directions, ME Sharpe, Armonk, NY, pp. 320-333.

Baron, S. and Harris, K. (2008), "Consumers as resource integrators", Journal of Marketing Management, Vol. 24 No. 1, pp. 113-130.

Bearden, W. O. and Etzel, M. J. (1982), "Reference group influence on product and brand purchase decisions", Journal of Consumer Research, Vol. 9 No. 2, pp. 183-194.

Begg, R. (2011), "Culturing commitment: serious leisure and the folk festival experience", in Gibson, C. and Connell, J. (eds.), Festival places: revitalising rural Australia, Channel View Publications, Bristol, pp. 248-264.

Belk, R. W. (1975), "Situational variables and consumer behavior", Journal of Consumer Research, Vol. 2 No. 3, pp. 157-164.

Binkhorst, E. and Den Dekker, T. (2009), "Agenda for co-creation tourism experience research", Journal of Hospitality Marketing \& Management, Vol. 18 No. 2, pp. 311327.

Bitner, M. J. (1992), "Servicescapes: the impact of physical surroundings on customers and employees", Journal of Marketing, Vol. 56 No. 2, pp. 57-71.

Cova, B. (1997), "Community and consumption: towards a definition of the "linking value" of product or services", European Journal of Marketing, Vol. 31 No. 3/4, pp. 297316.

Edvardsson, B., Tronvoll, B. and Gruber, T. (2011), "Expanding understanding of service exchange and value co-creation: a social construction approach", Journal of the Academy of Marketing Science, Vol. 39 No. 2, pp. 327-339.

Filimonau, V., Dickinson, J., Cherrett, T., Davies, N., Norgate, S. and Speed, C. (2013), "Rethinking travel networks: mobile media and collaborative travel in the tourism domain", paper presented at Universities Transport Study Group (UTSG) 45th Annual Conference, 2nd - 4th January 2013, Oxford, United Kingdom.

Finsterwalder, J. and Kuppelwieser, V. G. (2011), "Co-creation by engaging beyond oneself: the influence of task contribution on perceived customer-to-customer social interaction during a group service encounter", Journal of Strategic Marketing, Vol. 19 No. 7, pp. 607-618.

Gibson, C. and Connell, J. (2012), Music festivals and regional development in Australia, Ashgate Publishing Limited, Farnham.

Goulding, C. and Shankar, A. (2011), "Club culture, neotribalism and ritualised behaviour", Annals of Tourism Research, Vol. 38 No. 4, pp. 1435-1453.

Grönroos, C. (2008), "Service logic revisited: who creates value? And who co-creates?", European Business Review, Vol. 20 No. 4, pp. 298-314.

Grönroos, C. and Voima, P. (2013), "Critical service logic: making sense of value creation and co-creation", Journal of the Academy of Marketing Science, Vol. 41 No. 2, pp. 133-150.

Gummerus, J. (2013), "Value creation processes and value outcomes in marketing theory: strangers or siblings?", Marketing Theory, Vol. 13 No. 1, pp. 19-46.

Heinonen, K., Strandvik, T., Mickelsson, K. J., Edvardsson, B., Sundström, E. and Andersson, P. (2010), "A customer-dominant logic of service", Journal of Service Management, Vol. 21 No. 4, pp. 531-548.

Heinonen, K., Strandvik, T. and Voima, P. (2013), "Customer dominant value formation in service", European Business Review, Vol. 25 No. 2, pp. 104-123. 
Helkkula, A., Kelleher, C. and Pihlström, M. (2012), "Characterizing value as an experience: implications for service researchers and managers", Journal of Service Research, Vol. 15 No. 1, pp. 59-75.

Holbrook, M. B. (1999), "Introduction", in Holbrook, M. B. (ed.) Consumer value: a framework for analysis and research, Routledge, London, pp. 1-28.

Huang, J. and Hsu, C. H. C. (2010), "The impact of customer-to-customer interaction on cruise experience and vacation satisfaction", Journal of Travel Research, Vol. 49 No. 1, pp. 79-92.

Husserl, E. ([1936] 1970), The Crisis of European Sciences and Transcendental Phenomenology [trans. David Carr], Northwestern University Press, Evanston, IL.

Kim, H. and Jamal, T. (2007), "Touristic quest for existential authenticity", Annals of Tourism Research, Vol. 34 No. 1, pp. 181-201.

Kozinets, R. V. (2002), "Can consumers escape the market? Emancipatory illuminations from Burning Man", Journal of Consumer Research, Vol. 29 No. 1, pp. 20-38.

Kyle, G. and Chick, G. (2002), "The social nature of leisure involvement", Journal of Leisure Research, Vol. 34 No. 4, pp. 426-448.

Lehto, X. Y., Choi, S., Lin, Y.-C. and MacDermid, S. M. (2009), "Vacation and family functioning", Annals of Tourism Research, Vol. 36 No. 3, pp. 459-479.

Maffesoli, M. (1996 [1988]), The time of the tribes: the decline of individualism in mass society, Sage, London.

Martin, C. L. and Pranter, A. (1989), "Compatibility management: customer-to-customer relationships in service environments", Journal of Services Marketing, Vol. 3 No. 3, pp. 5-15.

McColl-Kennedy, J. R., Vargo, S. L., Dagger, T. S., Sweeney, J. C. and van Kasteren, Y. (2012), "Health care customer value cocreation practice styles", Journal of Service Research, Vol. 15 No. 4, pp. 370-389.

McGinnis, L. P., Gentry, J. W. and Gao, T. (2012), "Antecedents to consumer perceptions of sacredness in extended service experiences : the case of golf", Journal of Service Research, Vol. 15 No. 4, pp. 474-488.

McGrath, M. A. and Otnes, C. (1995), "Unacquainted influencers: when strangers interact in the retail setting", Journal of Business Research, Vol. 32 No. 3, pp. 261-272.

Neuhofer, B., Buhalis, D. and Ladkin, A. (2012), "Conceptualising technology enhanced destination experiences", Journal of Destination Marketing \& Management, Vol. 1 No.1/2, 36-46.

Pareigis, J., Echeverri, P. and Edvardsson, B. (2012), "Exploring internal mechanisms forming customer servicescape experiences", Journal of Service Management, Vol. 23 No. 5, pp. 677 - 695.

Payne, A. F., Storbacka, K. and Frow, P. (2008), "Managing the co-creation of value", Journal of the Academy of Marketing Science, Vol. 36 No. 1, pp. 83-96.

Pongsakornrungsilp, S. and Schroeder, J. E. (2011), "Understanding value co-creation in a co-consuming brand community", Marketing Theory, Vol. 11 No. 3, pp. 303-324.

Rosenbaum, M. S. (2008), "Return on community for consumers and service establishments", Journal of Service Research, Vol. 11 No. 2, pp. 179-196.

Rosenbaum, M. S. and Massiah, C. (2011), "An expanded servicescape perspective", Journal of Service Management, Vol. 22 No. 4, pp. 471 - 490.

Rowley, J., Kupiec-Teahan, B. and Leeming, E. (2007), "Customer community and cocreation: a case study", Marketing Intelligence and Planning, Vol. 25 No. 2, pp. 136146.

Russo-Spena, T. and Mele, C. (2012), "“Five Co-s" in innovating: a practice-based view", Journal of Service Management, Vol. 23 No. 4, pp. 527-553. 
Schau, H. J., Muñiz Jr, A. M. and Arnould, E. J. (2009), "How brand community practices create value", Journal of Marketing, Vol. 73 No. 5, pp. 30-51

Sheth, J. N., Newman, B. I. and Gross, B. L. (1991), "Why we buy what we buy: a theory of consumption values", Journal of Business Research, Vol. 22 No. 2, pp. 159-170.

Smith, W. J. (2012), "The new kinship economy: Profiting for process, people \& purpose", paper presented at the Direct Marketing Association Conference \& Exhibition, 13th 18th October, Mandalay Bay, Las Vegas, United States.

Storper, M. and Venables, A. J., 2004. Buzz: face-to-face contact and the urban economy. Journal of Economic Geography, 4 (4), 351-370.

Sweeney, J. C. and Soutar, G. N. (2001), "Consumer perceived value: the development of a multiple item scale", Journal of Retailing, Vol. 77 No. 2, pp. 203-220.

Turner, V. W. (1995), The ritual process: structure and anti-structure (with a foreword by Roger D. Abrahams), Aldine de Gruyter, New York, NJ.

Uhrich, S. and Benkenstein, M. (2011), "Physical and social atmospheric effects in hedonic service consumption: customers' roles at sporting events", The Service Industries Journal, Vol. 32 No. 11, pp. 1741-1757.

Vargo, S. L. and Lusch, R. F. (2006), "Evolving to a new dominant logic for marketing", in Lusch, R. F. and Vargo, S. L. (eds.), The service-dominant logic of marketing: dialog, debate, and directions, New York, NY, M.E. Sharpe, pp. 3-28.

Vargo, S. L. and Lusch, R. L. (2004), "Evolving to a new dominant logic for marketing", Journal of Marketing, Vol. 68 No. 1, pp. 1-17.

Vargo, S. L. and Lusch, R. L. (2008), "Service-dominant logic: continuing the evolution", Journal of the Academy of Marketing Science, Vol. 36 No. 1, pp. 1-10.

Voima, P., Heinonen, K. and Strandvik, T. (2010), "Exploring customer value formation: a customer dominant logic perspective", Working Paper No. 552 [Online], available from: https://helda.helsinki.fi/handle/10227/630 (accessed November 26, 2011).

Walker, C. J. (2010), "Experiencing flow: is doing it together better than doing it alone?", The Journal of Positive Psychology, Vol. 5 No. 1, pp. 3 - 11.

Wilks, L. J. (2012), "Social capital in the music festival experience", in Page, S. J. and Connell, J. (eds.), The Routledge handbook of events, Routledge, Abingdon, pp. 260272. 


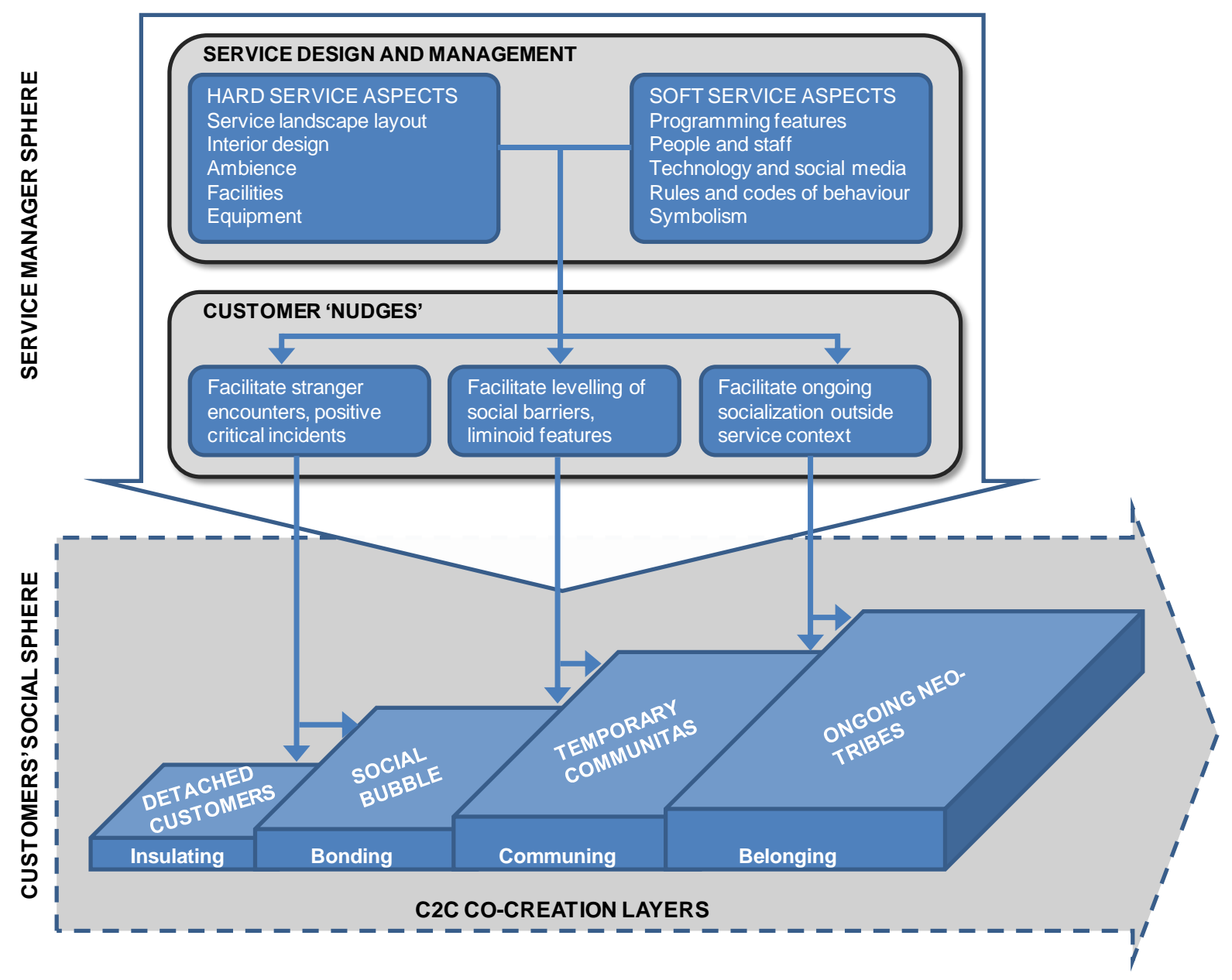


Table 1: Conceptualizing C2C co-creation layers

\begin{tabular}{|c|c|c|c|}
\hline $\begin{array}{l}\text { Co-creation } \\
\text { layers }\end{array}$ & $\begin{array}{l}\text { Who co- } \\
\text { creates }\end{array}$ & Characteristics & $\begin{array}{l}\text { Examples from service } \\
\text { literature }\end{array}$ \\
\hline $\begin{array}{l}\text { Detached } \\
\text { Customers }\end{array}$ & $\begin{array}{l}\text { Single } \\
\text { customers, } \\
\text { known- } \\
\text { customer } \\
\text { dyads } \\
\text { (couples, } \\
\text { pairs) }\end{array}$ & $\begin{array}{l}\text { Insularity-, privacy- } \\
\text { seeking } \\
\text { Relaxation and escapism } \\
\text { Affirmation of shared } \\
\text { consumption choices and } \\
\text { attitudes } \\
\text { Helping and assistance to } \\
\text { strangers may be present }\end{array}$ & $\begin{array}{l}\text { Day visitors at festivals (Wilks, } \\
\text { 2012) } \\
\text { Hospitality, entertainment, } \\
\text { leisure customers (Rosenbaum, } \\
\text { 2008) } \\
\text { Retail customers (McGrath and } \\
\text { Otnes, 1995) }\end{array}$ \\
\hline $\begin{array}{l}\text { Social } \\
\text { Bubble }\end{array}$ & $\begin{array}{l}\text { Known- } \\
\text { customer } \\
\text { groups } \\
\text { (families, } \\
\text { friends) }\end{array}$ & $\begin{array}{l}\text { Reinforcing of group/ } \\
\text { family rituals, roles and } \\
\text { traditions } \\
\text { Sharing and remembering } \\
\text { consumption experiences } \\
\text { (on- and off-line) } \\
\text { Strangers may be invited } \\
\text { into group activities and } \\
\text { rituals }\end{array}$ & $\begin{array}{l}\text { Families and friends visiting } \\
\text { festivals together (Gibson and } \\
\text { Connell, 2012; Kyle and } \\
\text { Chick, 2002; Lehto et al., } \\
\text { 2009) } \\
\text { Friendship groups in retail and } \\
\text { hospitality settings } \\
\text { (Rosenbaum, 2008). }\end{array}$ \\
\hline $\begin{array}{l}\text { Temporary } \\
\text { Communitas }\end{array}$ & $\begin{array}{l}\text { Un-known } \\
\text { temporary } \\
\text { customer } \\
\text { communities }\end{array}$ & $\begin{array}{l}\text { Breaking down of social } \\
\text { barriers, feelings of } \\
\text { goodwill and unity } \\
\text { Temporarily shared sense } \\
\text { of togetherness and } \\
\text { solidarity } \\
\text { Communing may } \\
\text { transcend physical setting }\end{array}$ & $\begin{array}{l}\text { Participants in adventure tours } \\
\text { and sport activities (Arnould } \\
\text { and Price, 1993; McGinnis et } \\
\text { al., 2012) } \\
\text { Festival attendees (Arnould } \\
\text { and Price, 1993; Begg, 2011; } \\
\text { Gibson and Connell, 2012). } \\
\text { Tourists at campsites } \\
\text { (Filimonau } \text { et al., 2013) } \\
\text { Customers in 'third places' } \\
\text { (Rosenbaum, 2008) }\end{array}$ \\
\hline $\begin{array}{l}\text { Ongoing } \\
\text { Neo-tribes }\end{array}$ & $\begin{array}{l}\text { Ongoing } \\
\text { customer } \\
\text { collectives } \\
\text { and neo- } \\
\text { tribes }\end{array}$ & $\begin{array}{l}\text { Regular consumption and } \\
\text { involvement in ongoing } \\
\text { collectives (on- and off- } \\
\text { line) } \\
\text { Identification through } \\
\text { symbolism centred on } \\
\text { specific activity, brand, } \\
\text { interest } \\
\text { Sharing of specialist } \\
\text { knowledge and resources }\end{array}$ & $\begin{array}{l}\text { Football fans } \\
\text { (Pongsakornrungsilp and } \\
\text { Schroeder, 2011) } \\
\text { Clubbers (Goulding and } \\
\text { Shankar, 2011) } \\
\text { Brand communities (Rowley et } \\
\text { al., 2007; Schau et al., 2009) } \\
\text { Committed festival attendees } \\
\text { (Begg, 2011; Kim and Jamal, } \\
\text { 2007) }\end{array}$ \\
\hline
\end{tabular}


